\title{
Some centipedes and millipedes (Myriapoda) new to the fauna of Belarus
}

\section{Некоторые губоногие и двупарноногие многоножки (Myriapoda), новые для фауны Беларуси}

\author{
A.M. Ostrovsky \\ A.M. Островский
}

Gomel State Medical University, Lange str. 5, Gomel 246000, Republic of Belarus. E-mail: Arti301989@mail.ru

Гомельский государственный медицинский университет, ул. Ланге 5, Гомель 246000, Республика Беларусь

KEY WORDS: Geophilus flavus, Lithobius crassipes, Lithobius microps, Blaniulus guttulatus, faunistic records, Belarus

КЛЮЧЕВЫЕ СЛОВА: Geophilus flavus, Lithobius crassipes, Lithobius microps, Blaniulus guttulatus, фаунистика, Беларусь

ABSTRACT. The first records of three species of centipedes and one species of millipede from Belarus are provided. All records are clearly synathropic.

РЕЗЮМЕ. Приведены сведения о фаунистических находках трёх новых видов губоногих и одного вида двупарноногих многоножек в Беларуси. Все находки явно синантропные.

The myriapod fauna of Belarus is still poorly-known. According to various authors, 10-11 species of centipedes [Meleško, 1981; Maksimova, 2014; Ostrovsky, 2016, 2018] and 28-29 species of millipedes [Lokšina, 1964, 1969; Tarasevich, 1992; Maksimova, Khot'ko, 1997; Maksimova, 2002; Šinkevich, 2006] have hitherto been recorded from the country. The myriapods in Belarus have mainly been reported from natural or semi-natural habitats. New records of myriapods from anthropogenic habitats in the city of Minsk allow for the list to be enriched by four synanthropic species.

The new samples are kept in the author's private collection.

\section{CLASS CHILOPODA ORDER GEOPHILOMORPHA Family GEOPHILIDAE}

Geophilus flavus (De Geer, 1778)

MATERIAL EXAMINED. 2 9 , Republic of Belarus, Minsk, Krasivyi lane, among household waste, 14.07.2019, leg. et det. A.M. Ostrovsky.

DISTRIBUTION. A widespread Euro-Siberian species distributed in the western Palaearctic, ranging from northwestern Africa through most of Europe to Siberia; also introduced to North America [Bonato et al., 2005; Nefediev et al., 2017]. The published synonymy of Schizotaenia ornata Folkmanová et Dobroruka, 1960 under G. flavus by Bonato and Minelli [2014] implies that there may be some previous records of G. flavus from the former USSR, including Belarus, reported under the name of G. proximus C.L. Koch, 1847 [Zalesskaja et al., 1982]. The distribution of $G$. flavus in European Russia has been summarized by Volkova [2016].

\section{ORDER LITHOBIOMORPHA Family LITHOBIIDAE}

\section{Lithobius (Monotarsobius) crassipes C.L. Koch, 1862}

MATERIAL EXAMINED. 1 , Republic of Belarus, Minsk, Krasivyi lane, among household waste, 14.07.2019, leg. et det. A.M. Ostrovsky.

DISTRIBUTION. A western Palaearctic species widespread across Europe, ranging from the Canary Islands and northern Africa in the west, through the Near East, the Caucasus and European Russia, to western and central Siberia in the east; also introduced to Taiwan and the U.S.A. In the European part of Russia, it has been found in the Moscow, Ulyanovsk and Rostov-on-Don areas, the republics of Karelia, Adygea, Komi and Crimea, the Krasnodar, Perm and Stavropol provinces and the Nenets Autonomous Region in the Arkhangelsk Area (Vaygach Island), while in Asian Russia in the Krasnoyarsk Province (Vorogovo and NizhneImbatsk), the Altai Province and the Tyumen Area [Lohmander, 1925; Palmén, 1948, 1988; Minoranskij, 1977; Zalesskaja, 1978; Wytwer, 1999; Farzalieva, 2008; Zapparoli, 2009, 2011; Sergeeva, 2013; Volkova, 2014; Zuev, 2016; Nefediev et al., 2016; Tuf et al., 2015; Sammet et al., 2018].

Lithobius (Sigibius) microps Meinert, 1868

MATERIAL EXAMINED. 1 , Republic of Belarus, Minsk, Krasivyi lane, among household waste, 14.07.2019, leg. et det. A.M. Ostrovsky.

DISTRIBUTION. A western Palaearctic species widespread in Europe, ranging from Portugal, Ireland and Great Britain in the west to Poland, Ukraine, and Turkey in the east;

How to cite this article: Ostrovsky A.M. 2021. Some centipedes and millipedes (Myriapoda) new to the fauna of Belarus // Russian Entomol. J. Vol.30. No.1. P.106-108. doi: 10.15298/rusentj.30.1.14 
also introduced to North America (Canada, U.S.A.) and Australia (Tasmania) [Palmén, 1948, 1988; Stoev, 2000, 2001; Zapparoli, 2002; Andersson et al., 2005; Tuf et al., 2015; Bonato et al., 2016; Sammet et al., 2018].

\section{CLASS DIPLOPODA ORDER JULIDA Family BLANIULIDAE}

\section{Blaniulus guttulatus (Fabricius, 1798)}

MATERIAL EXAMINED. $90^{7} \sigma^{7}, 11$ 우, Republic of Belarus, Minsk, Krasivyi lane, among household waste, 14.07.2019, leg. et det. A.M. Ostrovsky.

DISTRIBUTION. A western Palaearctic species widespread across most of Europe, ranging from the Canary and Azores islands, Portugal, Iceland, Ireland and Great Britain in the west to Poland, Ukraine, and the central and northwestern parts of European Russia in the east; also introduced to Canada, U.S.A., St. Helena, Tristan da Cunha and Norfolk islands [Kime, Enghoff, 2017]. In the European part of Russia, it has been recorded from the Kaliningrad, Moscow and Leningrad areas, and the Perm Province [Lokšina, 1969; Atlavinyte, Lokšina, 1971; Zalesskaja et al., 1982; Andersson et al., 2008; Spuòìs, 2010; Kime, Enghoff, 2017; Kozminykh, 2018].

The above four myriapod species are formally new to the fauna of Belarus. All of them have been found in the city of Minsk and all seem to be associated with synanthropic habitats. During my survey of the Minsk myriapod fauna, the following species have also been recorded: Lithobius $(L$. forficatus (Linnaeus, 1758), L. (Monotarsobius) curtipes C.L. Koch, 1847, Polydesmus denticulatus C.L. Koch, 1847 , Proteroiulus fuscus (Am Stein, 1857) and Cylindroiulus caeruleocinctus (Wood, 1864).

\section{References}

Andersson G., Djursvoll P., Scheller U. 2008. Katalog över Nordens mångfotingar // Entomologisk Tidskrift. Vol.129. P.173-190 [in Swedish].

Andersson G., Meidell B., Scheller U., Djursvoll P., Budd G., Gärdenfors U. 2005. Nationalnyckeln till Sveriges flora och fauna Mångfotingar Myriapoda. Uppsala: ArtDatabanken Sveriges Lantbruksuniversitet. 351 p. [in Swedish].

Atlavinytė O., Lokšina I. 1971. [Millipedes of the Lithuanian SSR] // Lietuvos TRS Mokslu akademijos darbai. C serja. Vol.55. No.2. P.83-92 [in Russian].

Bonato L., Chagas Jr A., Edgecombe G.D. Lewis J.G.E., Minelli A., Pereira L.A., Shelley R.M., Stoev P., Zapparoli M. 2016. ChiloBase 2.0 - A World Catalogue of Centipedes (Chilopoda). Available at: https://chilobase.biologia.unipd.it/ (accessed 10 January 2021)

Bonato L., Minelli A. 2014. Chilopoda Geophilomorpha of Europe: a revised list of species with taxonomic and nomenclatural notes // Zootaxa. Vol.3770. No.1. P.1-136.

Bonato L., Minelli A., Spungis V. 2005. Geophilomorph centipedes of Latvia (Chilopoda, Geophilomorpha) // Latvijas Entomologs. Vol.42. No.1. P.5-17.

Farzalieva G.Sh. 2008. [The fauna and chorology of Myriapoda from the Urals and Cisuralia]. PhD Thesis. Perm State University. 189 pp. [In Russian]

Kime R.D., Enghoff H. 2017. Atlas of European millipedes 2: Order Julida (Class Diplopoda) // European Journal of Taxonomy. Vol.346. P.1-299.

Kozminykh V. 2018. [A catalogue of myriapods (Myriapoda) of the Urals] // Eversmannia. Vol.55-56. P.12-37 [in Russian, with English summary].
Lohmander H. 1925. Chilopoda, Diplopoda and Isopoda terrestria // A. Jansson (Ed.). Die Insekten-, Myriopoden- und Isopoden-fauna der Gotska Sandön. Örebro: Länstidningens Tryckeri Publ. P.167169.

Lokšina I.E. 1964. [Diplopoda in forest soils of Bielovezhskaja pushcha] // Pedobiologia. Vol.4. P.299-309 [in Russian].

Lokšina I.E. 1969. [Keys to the millipedes (Diplopoda) of the plain areas of the European part of the USSR]. Moscow: Nauka Publ. 78 pp. [in Russian].

Maksimova S.L. 2002. [New species of millipedes (Myriapoda, Diplopoda) for Belarus] // Proceedings of the National Academy of Sciences of Belarus. Biological series. No.3. P.117-118 [in Russian].

Maksimova S.L. 2014. [A list of centipede (Myriapoda, Chilopoda) species occurring of Belarus] // Proceedings of the National Academy of Sciences of Belarus. Series of Biological Sciences. No.4. P.91-94 [in Russian].

Maksimova S.L., Khot'ko E.I. 1997. [Diplopoda] // E.I. Khot'ko (ed.). Bespozvonochnye Natsional'nogo parka "Pripyatskii”". Minsk. P.19-22 [in Russian].

Meleško Ya.S. 1981. [Changes in the soil mesofauna of grey alder forests under the influence of land reclamation and agricultural development in the north-east of Belarus]. PhD Thesis. Academy of Sciences of the BSSR, Institute of Zoology. 173 pp. [in Russian].

Minoranskij V.A. 1977. [Some data on Chilopoda (Myriapoda) from the Rostov Region] // Vestnik zoologii. No.4. P.38-43 [in Russian].

Nefediev P.S., Tuf I.H., Farzalieva G.Sh. 2016. Centipedes from urban areas in southwestern Siberia, Russia (Chilopoda). Part 1. Lithobiomorpha // Arthropoda Selecta. Vol.25. No.3. P.257-266.

Nefediev P.S., Tuf I.H., Farzalieva G.Sh. 2017. Centipedes from urban areas in southwestern Siberia, Russia (Chilopoda). Part 2. Geophilomorpha // Arthropoda Selecta. Vol.26. No.1. P.8-14.

Ostrovsky A.M. 2016. The first records of Scutigera coleoptrata (Linnaeus, 1758) (Chilopoda: Scutigeromorpha: Scutigeridae) from Belarus // Arthropoda Selecta. Vol.25. No.4. P.355-356.

Ostrovsky A.M. 2018. The first record of Cryptops hortensis (Donovan, 1810) (Chilopoda: Scolopendromorpha: Cryptopidae) in Belarus // Arthropoda Selecta. Vol.27. No.1. P.31-32.

Palmén E. 1948. The Chilopoda of Eastern Fennoscandia // Annales Zoologici Societatis Zoologicae-Botanicae Fennicae Vanamo. Vol.13. P.1-54.

Palmén E. 1988. [Myriapoda of Eastern Scandinavia] // D.A. Krivolutzkij (ed.). Soil Biology of Northern Europe. Moscow: Nauka Publ. P.16-40 [in Russian]

Sammet K., Ivask M., Kurina O. 2018. A synopsis of Estonian myriapod fauna (Myriapoda: Chilopoda, Diplopoda, Symphyla and Pauropoda) // ZooKeys. Vol.793. P.63-96. https://doi.org/ 10.3897/zookeys.793.28050.

Sergeeva E.V. 2013. [Biotopic distribution and number of centipedes (Chilopoda) in the Irtysh valley of West Siberia, Russia] // Euroasian Entomological Journal. Vol.12. No.6. P.529-533 [in Russian, with English summary].

Šnkevich N.V. 2006. [Species diversity of millipedes (Myriapoda: Diplopoda) in spruce forests of different ages in the subzone of oak-dark coniferous forests of Belarus] // Proceedings of the National Academy of Sciences of Belarus. Biological series. No.5. P.223-227 [in Russian].

Spungisis V. 2010. Fauna of millipedes (Diplopoda) in Latvia with notes on occurrence, habitat preference and abundance // Latvijas Entomologs. Vol.48. P.107-115.

Stoev P. 2000. On centipedes (Chilopoda) of Albania, 2 // Arthropoda Selecta. Vol.9. No.3. P.199-206.

Stoev P. 2001. A synopsis of the Bulgarian cave centipedes (Chilopoda) // Arthropoda Selecta. Vol.10. No.1. P.31-54.

Tarasevich Yu.L. 1992. Diplopoda in the associations of mixed forests in Byelorussia // Proceedings of the 8th International Congress of Myriapodology. Berichte des naturwissenschaftlich-medizinischen Vereins Innsbruck. Suppl.10. P.213-218.

Tuf I.H., Ivinskis P., Rimšaite J. 2015. A checklist of the centipedes (Chilopoda) of Lithuania // Zootaxa. Vol.4052. No.3. P.394-400.

Volkova Yu.S. 2014. [The fauna of predatory myriapods of the Simbirsk Volga Region] // Priroda Simbirskogo Povolzhiya. 
Sbornik nauchnykh trudov XVI mezhregionalnoj nauchno-prakticheskoy konferentsii "Estestvennonauchnye issledovaniya $\mathrm{V}$ Simbirskom-Ulyanovskov krae". Vol.15. P.95-103 [in Russian].

Volkova Yu.S. 2016. [An annotated catalogue of geophilomorph centipedes (Myriapoda, Geophilomorpha) from the European part of Russia] // Zoologicheskii zhurnal. Vol.95. No.6. P.669678 [in Russian with English summary].

Wytwer J. 1999. State of faunistical knowledge of the centipedes (Chilopoda) of Białowieża Forest // Parky Narodowe i Rezerwaty Przyrody. Suppl.18. P.61-65 [in Polish].

Zalesskaja N.T. 1978. [Identification book of the lithobiomorph centipedes of the USSR]. Moscow: Nauka Publ.212pp. [In Russian]

Zalesskaja N.T., Titova L.P., Golovatch S.I. 1982. [The myriapod fauna of the Moscow Region] // M.S. Ghilarov (ed.). Pochvennye bespozvonochnye Moskovskoi oblasti. Moscow: Nauka Publ. P.179-200 [in Russian]
Zapparoli M. 2002. Catalogue of the centipedes from Greece (Chilopoda)//Fragmenta Entomologica. Vol.34. P.1-146.

Zapparoli M. 2009. An annotated catalogue of the epigeic and cave centipedes (Chilopoda) of Sardinia // P. Cerretti, F. Mason, A. Minelli, G. Nardi, D. Whitmore. (eds.). Research on the Terrestrial Arthropods of Sardinia(Italy). Zootaxa. Vol.2318. P.56-168.

Zapparoli M. 2011. New records and remarks on the centipede fauna of endogean habitats of Sardinia (Chilopoda) // Nardi G., Whitmore D., Bardiani M., Birtele D., Mason F., Spada L., Cerretti P. (eds.). Biodiversity of Marganai and Montimannu (Sardinia). Research in the framework of the ICP Forests network. Conservazione Habitat Invertebrati. No.5. P.223-242.

Zuev R.V. 2016. Centipedes (Chilopoda) from the Stavropol Territory, northern Caucasus, Russia // Arthropoda Selecta. Vol.25. No.1. P.23-38. 